\title{
KEEFEKTIFAN MODEL KOOPERATIF TIPE CONCEPT SENTENCE DAN TIPE THINK-PAIR-SHARE DALAM PEMBELAJARAN MENULIS DESKRIPSI
}

\author{
Yeni Rahmawati dan Nurhadi \\ Ganesha Operation ${ }^{1)}$, Universitas Negeri Yogyakarta ${ }^{2)}$ \\ email: yenirahma5@gmail.com ${ }^{1)}$,nurhadi2@yahoo.co.id ${ }^{2)}$
}

\begin{abstract}
ABSTRAK
Penelitian ini bertujuan untuk mengetahui (1) perbedaan yang signifikan antara model kooperatif tipe concept sentence, model kooperatif tipe think-pair-share, dan model tradisional dalam pembelajaran menulis deskripsi peserta didik kelas VII SMP Negeri di Kabupaten Sleman (2) manakah yang lebih efektif antara model kooperatif tipe concept sentence, model kooperatif tipe think-pair-share, dan model tradisional dalam pembelajaran menulis deskripsi peserta didik kelas VII SMP Negeri di Kabupaten Sleman. Penelitian ini menggunakan metode eksperimen semu dengan desain Randomized Control-Group Pretest-Posttest Design. Penelitian ini dilakukan di SMP N 3 Gamping, SMP N 2 Godean, dan SMP N 2 Gamping. Hasil penelitian menunjukkan bahwa terdapat perbedaan penggunaan model kooperatif tipe concept sentence, model kooperatif tipe think-pair-share, dan model tradisional dalam pembelajaran menulis deskripsi dengan nilai $\mathrm{F}=140,578$ dan $\operatorname{sig}(p)<0,05$. Selanjutnya, model kooperatif tipe think-pair-share paling efektif dalam pembelajaran menulis deskripsi daripada model kooperatif tipe concept sentence dan model tradisional.
\end{abstract}

Kata Kunci: keefektifan, concept sentence, think-pair-share, deskripsi

\section{THE EFFECTIVENESS OF THE COOPERATIVE MODELS OF THE CONCEPT SENTENCE TYPE AND THE THINK-PAIR-SHARE TYPE IN THE LEARNING OF THE DESCRIPTIVE WRITING}

\begin{abstract}
This study aims to investigate (1) significant difference between cooperative model type concept sentence, cooperative model type think-pair-share, and traditional model for the learning of the descriptive writing among Grade VII students at junior high schools (JHSs) in Sleman Regency (2) which one is the most effective among the cooperative model of the concept sentence type, that of the think-pair-share type, and the traditional model for the learning of the descriptive writing among Grade VII students at junior high schools (JHSs) in Sleman Regency. This was an experimental study employing the randomized control-group pretest-posttest design. This research was conducted in SMP N 3 Gamping, SMP N 2 Godean, and SMP N 2 Gamping.The results of the study were as follows there was a difference among the application of the cooperative model of the concept sentence type, that of the think-pair-share type, and the traditional model in the learning of the descriptive writing with $\mathrm{F}=140.578$ and a significance value $(\mathrm{p})<$ 0.05 . Furthermore, the cooperative model of the think-pair-share was the most effective for the learning of the descriptive writing in comparison with the cooperative model of the concept sentence type and the traditional model.
\end{abstract}

Keywords: effectiveness, concept sentence, think-pair-share, descriptive

\section{PENDAHULUAN}

Ada beberapa jenis menulis, salah satu di antaranya adalah menulis deskripsi. Deskripsi adalah karangan yang melukiskan sesuatu dengan keadaan yang sebenarnya sehingga pembaca dapat mencitrai apa yang dilukiskan sesuai dengan citra penulisnya. Karangan deskripsi bertujuan untuk menggambarkan atau 
melukiskan tentang suatu hal secara sistematis dan jelas kepada pembaca. Selain itu, tujuan menulis deskripsi adalah mengajak para pembaca menikmati, merasakan, memakai sebaikbaiknya objek, adegan, dan kegiatan orang atau suasana hati yang telah dialami oleh penulis. Penulis dituntut mampu menggambarkan atau melukiskan tentang suatu keadaan atau hal sehingga orang yang membaca tulisan tersebut seolah-olah berada di tempat tersebut. Dalam karangan deskripsi, penulis memindahkan kesan-kesannya, memindahkan hasil pengamatan, dan perasaannya kepada para pembaca. Selain itu, penulis juga menyampaikan sifat dan semua perincian wujud yang dapat ditemukan pada objek tersebut. Sasaran yang ingin dicapai oleh seorang penulis deskripsi adalah menciptakan atau memungkinkan terciptanya daya khayal (imajinasi) pada para pembaca, seolah-olah mereka melihat sendiri objek tadi secara keseluruhan sebagai yang dialami secara fisik oleh penulisnya (Keraf, 1981: 93).

Pembelajaran menulis, khususnya menulis deskripsi penting dilakukan. Hal ini disebabkan kemampuan menulis merupakan bekal peserta didik untuk jenjang yang lebih tinggi. Umumnya, pembelajaran menulis deskripsi di sekolah masih menggunakan model tradisional. Untuk itu, perlu diberikan model pembelajaran yang kreatif fan inovatif. Penelitian ini menggunakan model kooperatif tipe concept sentence dan model pembelajaran tipe think-pair-share dalam pembelajaran menulis deskripsi.

Dari hasil prasurvei yang dilakukan di SMP Negeri 2 Gamping, SMP Negeri 3 Gamping, dan SMP Negeri 2 Godean, guru belum pernah menggunakan model pembelajaran kooperatif tipe concept sentence dan think-pairshare dalam pembelajaran menulis karangan deskripsi. Guru mengajar dengan menggunakan kemampuan verbal. Cara mengajar guru tersebut membuat peserta didik merasa bosan jika diberikan tugas menulis khususnya menulis karangan deskripsi. Para peserta didik biasanya menyukai sesuatu hal yang baru. Oleh karena itu, peneliti mencoba menerapkan model pembelajaran kooperatif tipe concept sentence dan think-pairshare dalam pembelajaran menulis deskripsi. Model pembelajaran kooperatif tipe concept sentence dan think-pair-share diharapkan efektif dalam pembelajaran menulis karangan deskripsi peserta didik kelas VII SMP.

Faktor-faktor inilah yang mendorong penulis mengadakan penelitian tentang keefektifan model kooperatif tipe concept sentence dan model kooperatif tipe think-pair-share dalam pembelajaran menulis deskripsi peserta didik kelas VII SMP. Selama ini belum diketahui pasti keefektifan model kooperatif tipe concept sentence dan model kooperatif tipe think-pair-share dalam pembelajaran menulis deskripsi sehingga perlu adanya penelitian tentang keefektifan penggunaan model pembelajaran tersebut. Penelitian ini akan menguji apakah model-model tersebut efektif dalam pembelajaran menulis deskripsi peserta didik kelas VII SMP Negeri di Kabupaten Sleman.

Penelitian ini bertujuan untuk mengetahui (1) perbedaan yang signifikan antara model kooperatif tipe concept sentence, model kooperatif tipe think-pair-share, dan model tradisional dalam pembelajaran menulis deskripsi peserta didik kelas VII SMP Negeri di Kabupaten Sleman (2) manakah yang lebih efektif antara model kooperatif tipe concept sentence, model kooperatif tipe think-pair-share, dan model tradisional dalam pembelajaran menulis deskripsi peserta didik kelas VII SMP Negeri di Kabupaten Sleman.

Huda (2014: 315) menyatakan bahwa concept sentence merupakan strategi pembelajaran yang dilakukan dengan memberikan kartu-kartu yang berisi beberapa kata kunci kepada peserta didik, kemudian kata kunci-kata kunci tersebut disusun menjadi beberapa kalimat dan dikembangkan menjadi paragraf-paragraf. Pembelajaran semacam ini dilakukan untuk mengembaangkan kreativitas peserta didik agar kemampuan berpikirnya lebih berkembang.

Arends (2008: 15) menyatakan bahwa think-pair-share adalah suatu model yang menantang asumsi bahwa semua resitasi atau diskusi perlu dilakukan dalam setting seluruh kelompok dan memiliki prosedur-prosedur built-in untuk memberikan lebih banyak waktu kepada peserta didik untuk berpikir, merespons, dan saling membantu. Pembelajaran menggunakan model kooperatif tipe think-pair-share ini dapat melatih peserta didik untuk bekerja sama dengan peserta didik lainnya. Dalam kegiatan 
pembelajaran Bahasa Indonesia sering ditemui bahwa ketika peserta didik mengerjakan tugas tertulis, peserta didik sering mencoba untuk langsung mengarang. Walaupun hal itu bukan sesuatu yang salah, namun akan lebih bermakna jika dia terlebih dahulu melakukan kegiatan berpikir, merefleksikan, dan menyusun ide-ide, serta menguji ide-ide itu sebelum memulai menulisnya. Model think-pair-share yang dipilih pada penelitian ini dibangun dengan memfasilitasi peserta didik untuk melakukan kegiatan berpikir, merefleksikan, dan menyusun ide-ide, serta menguji ide-ide itu sebelum menulisnya.

\section{METODE}

\section{Jenis Penelitian}

Penelitian ini merupakan penelitian kuantitatif dengan pendekatan eksperimen semu. Penelitian ini menggunakan desain eksperimen dengan Randomized Control-Group Pretest-Posttest Design (Campbell \& Stanley, 1972: 13). Pembelajaran ini menggunakan dua kelompok, yaitu kelompok eksperimen dan kelompok kontrol yang diawali dengan pretes dan diakhiri dengan postes. Pembelajaran ini melibatkan tiga variabel bebas, yaitu model pembelajaran kooperatif tipe concept sentence (X1), model kooperatif tipe think-pair-share (X2), dan model tradisional (X3). Variabel terikatnya adalah pembelajaran menulis deskripsi peserta didik.

\section{Waktu dan Tempat Penelitian}

Penelitian ini dilakukan di SMP Negeri 2 Gamping, SMP Negeri 3 Gamping, dan SMP Negeri 2 Godean yang terletak di wilayah Barat Kabupaten Sleman, Daerah Istimewa Yogyakarta tahun ajaran 2014/2015 pada bulan Oktober-November 2014 pada semester 1 tahun ajaran 2014/2015 sebanyak 6 kali pertemuan di setiap kelas.

\section{Populasi dan Sampel Penelitian}

Populasi penelitian ini seluruh peserta didik kelas VII SMP Negeri di Kabupaten Sleman. Penentuan kelompok eksperimen dan kelompok kontrol dilakukan dengan cluster random sampling. Sampel penelitian ini adalah
SMP Negeri 3 Gamping sebagai kelas eksperimen 1, SMP Negeri 2 Godean sebagai kelas eksperimen 2, dan SMP Negeri 2 Gamping sebagai kelas kontrol. Masing-masing kelas diambil 30 peserta didik secara acak sehingga sampel berjumlah 90 peserta didik.

\section{Prosedur Eksperimen}

Pada tahap praeksperimen dilakukan beberapa kegiatan, yaitu pelatihan guru pelaksana eksperimen, menyiapkan bahan pembelajaran, dan menentukan sampel penelitian. Pada tahap eksperimen dilakukan perlakuan sebanyak 6 kali pertemuan, selanjutnya, tahap pasca eksperimen guru memberikan tugas kepada peserta didik untuk menulis karangan deskripsi dan peneliti melakukan analisis data.

\section{Teknik Pengumpulan Data}

Teknik pengumpulan data dilakukan dengan metode nontes yang berupa penugasan menulis karangan deskripsi. Penilaian dilakukan sebanyak dua kali, yaitu sebelum perlakuan dan sesudah perlakuan.

\section{Instrumen Pengumpulan Data}

Instrumen pengumpulan data dilakukan dengan menggunakan instrumen lembar penilaian menulis karangan deskripsi. Kriteria penilaian berisi faktor-faktor yang berkaitan dengan penilaian karangan seperti yang diungkapkan oleh Brown (2003: 246). Adapun pedoman penilaian menurut Brown (2003: 246), yaitu isi gagasan, organisasi, struktur deskripsi, tata bahasa, dan ejaan.

\section{Teknik Analisis Data}

Teknik analisis data yang digunakan dalam penelitian ini adalah Anava satu jalur. Dalam melakukan teknik analisis statistik Anava, data yang akan dianalisis harus memenuhi beberapa kriteria, yaitu (1) normalitas dan (2) homogenitas. selanjutnya dilakukan uji scheffe untuk mengetahui urutan keefektifan pembelajaraan menulis deskripsi dari ketiga model pembelajaran, yaitu model kooperatif tipe concept sentence, model kooperatif tipe think-pair-share, dan model tradisional. Semua perhitungan dilakukan dengan SPSS versi 17. 


\section{HASIL DAN PEMBAHASAN}

Data berupa penilaian pembelajaran menulis deskripsi peserta didik kelas VII diperoleh dengan instrumen lembar penilaian menulis deskripsi. penilaian dilakukan sebanyak dua kali, yatiu sebelum (pretes) dan sesudah (postes) pembelajaran menulis deskripsi peserta didik kelas VII. Pretes dilaksanakan pada tanggal 28 Oktober 2014 kelas eksperimen 1, tanggal 30 Oktober 2014 kelas eksperimen 2, dan 3 November 2014 kelas kontrol. Sementara itu, postes dilaksanakan pada tanggal 22 November 2014 kelas eksperimen 1, tanggal 20 November 2014 kelas eksperimen 2, dan 26 November 2014 kelas kontrol.

\section{Deskripsi Kemampuan Awal}

Adapun hasil pretes pembelajaran menulis deskripsi peserta didik dapat dilihat pada Tabel 1 sebagai berikut.

Tabel 1. Pretes Pembelajaran Menulis Deskripsi

\begin{tabular}{lccc}
\hline & $\begin{array}{c}\text { Kelas } \\
\text { Eksperimen } \\
1\end{array}$ & $\begin{array}{c}\text { Kelas } \\
\text { Eksperimen }\end{array}$ & $\begin{array}{c}\text { Kelas } \\
\text { Kontrol }\end{array}$ \\
\hline $\mathrm{N}$ & 30 & 30 & 30 \\
Mean & 45,77 & 47,43 & 49,67 \\
Median & 44,00 & 48,00 & 51,00 \\
SD & 7,079 & 8,605 & 8,023 \\
Variance & 50,116 & 74,047 & 64,368 \\
Min. & 34 & 28 & 27 \\
Max. & 63 & 61 & 62 \\
\hline
\end{tabular}

Kelas Eksperimen 1

Peserta didik kelas eksperimen 1 adalah peserta didik kelas VII SMP Negeri 3 Gamping yang berjumlah 30 peserta didik. Pembelajaran menulis deskripsi dilakukan dengan menggunakan model kooperatif tipe concept sentence.

Tabel 2. Distribusi Frekuensi Pretes Kelas Eksperimen 1

\begin{tabular}{|c|c|}
\hline Interval & Frekuensi \\
\hline $59-63$ & 1 \\
\hline $54-58$ & 4 \\
\hline $49-53$ & 5 \\
\hline $44-48$ & 6 \\
\hline $39-43$ & 11 \\
\hline $34-38$ & 3 \\
\hline $\mathrm{N}$ & 30 \\
\hline
\end{tabular}

Berdasarkan Tabel 1 tersebut dapat diketahui bahwa hasil pretes kelas eksperimen 1 yang memperoleh skor 59-63 sebanyak 1, yang memperoleh skor 54-58 sebanyak 4, yang memperoleh skor 49-53 sebanyak 5, yang memperoleh skor 44-48 sebanyak 6, yang memperoleh skor 39-43 sebanyak 11, dan yang memperoleh skor 34-38 sebanyak 3. Dari tabel di atas diketahui bahwa yang memperoleh frekuensi terbanyak terdapat pada interval 39-43 yang berjumlah 11 peserta didik.

\section{Kelas Eksperimen 2}

Peserta didik kelas eksperimen 2 adalah peserta didik kelas VII SMP Negeri 2 Godean yang berjumlah 30 peserta didik. Pembelajaran menulis deskripsi dilakukan dengan menggunakan model kooperatif tipe think-pair-share.

Tabel 2 Distribusi Frekuensi Pretes Kelas Eksperimen 2

\begin{tabular}{c|c}
\hline Interval & Frekuensi \\
\hline $58-63$ & 4 \\
$52-57$ & 5 \\
$46-51$ & 14 \\
$40-45$ & 2 \\
$34-39$ & 2 \\
$28-33$ & 3 \\
$\mathrm{~N}$ & 30 \\
\hline
\end{tabular}

Berdasarkan Tabel 2 tersebut dapat diketahui bahwa hasil pretes kelas eksperimen 2 yang memperoleh skor 58-63 sebanyak 4, yang memperoleh skor 52-57 sebanyak 5, yang memperoleh skor 46-51 sebanyak 14, yang memperoleh skor 40-45 sebanyak 2, yang memperoleh skor 34-39 sebanyak 2, dan yang memperoleh skor 28-33 sebanyak 3 . Dari tabel di atas diketahui bahwa yang memperoleh frekuensi terbanyak terdapat pada interval 46-51 yang berjumlah 14 peserta didik.

\section{Kelas Kontrol}

Peserta didik kelas kontrol adalah peserta didik kelas VII SMP Negeri 2 Gamping yang berjumlah 30 peserta didik. Pembelajaran menulis deskripsi dilakukan tanpa menggunakan model kooperatif tipe concept sentence dan think-pair-share. 
Tabel 3. Distribusi Frekuensi Pretes Kelas Kontrol

\begin{tabular}{c|c}
\hline Interval & Frekuensi \\
\hline $59-66$ & 4 \\
$51-58$ & 13 \\
$43-50$ & 8 \\
$35-42$ & 3 \\
$27-34$ & 2 \\
$\mathrm{~N}$ & 30 \\
\hline
\end{tabular}

Berdasarkan Tabel 3 tersebut dapat diketahui bahwa hasil pretes kelas kontrol yang memperoleh skor 59-66 sebanyak 4, yang memperoleh skor 51-58 sebanyak 13, yang memperoleh skor 43-50 sebanyak 8, yang memperoleh skor 35-42 sebanyak 3, dan yang memperoleh skor 27-34 sebanyak 2. Dari tabel di atas diketahui bahwa yang memperoleh frekuensi terba-nyak terdapat pada interval 51-58 yang berjumlah 13 peserta didik.

\section{Deskripsi Kemampuan Akhir}

Postes dilaksanakan setelah eksperimen. Deskripsi hasil penilaian menulis deskripsi menulis deskripsi dapat dilihat pada Tabel 4 sebagai berikut.

Tabel 4. Postes Pembelajaran Menulis Deskripsi

\begin{tabular}{lccc}
\hline & $\begin{array}{c}\text { Kelas } \\
\text { Eksperimen } \\
1\end{array}$ & $\begin{array}{c}\text { Kelas } \\
\text { Eksperimen } \\
2\end{array}$ & $\begin{array}{c}\text { Kelas } \\
\text { Kontrol }\end{array}$ \\
\hline $\mathrm{N}$ & 30 & 30 & 30 \\
Mean & 77,00 & 80,63 & 60,27 \\
Median & 78,50 & 81,00 & 61,00 \\
SD & 5,540 & 4,767 & 4,705 \\
Variance & 30,690 & 22,723 & 22,133 \\
Min. & 63 & 74 & 47 \\
Max. & 85 & 94 & 70 \\
\hline
\end{tabular}

Kelas Eksperimen 1

Tabel 5. Distribusi Frekuensi Postes Kelas Eksperimen 1

\begin{tabular}{c|c}
\hline Interval & Frekuensi \\
\hline $81-86$ & 10 \\
$75-80$ & 8 \\
$69-74$ & 10 \\
$63-68$ & 2 \\
$\mathrm{~N}$ & 30 \\
\hline
\end{tabular}

Berdasarkan Tabel 5 tersebut dapat diketahui bahwa hasil postes kelompok eksperimen 1 yang memperoleh skor 81-86 sebanyak 10 , yang memperoleh skor 75-80 sebanyak 8 , yang memperoleh skor 69-74 sebanyak 10, dan yang memperoleh skor 63-68 sebanyak 2. Dari tabel di atas diketahui bahwa yang memperoleh frekuensi terbanyak terdapat pada interval 69-74 dan interval 81-86 yang masing-masing berjumlah 10 peserta didik.

Kelas Eksperimen 2

Tabel 6. Distribusi Frekuensi Postes Kelas Eksperimen 2

\begin{tabular}{c|c}
\hline Interval & Frekuensi \\
\hline $94-98$ & 1 \\
$89-93$ & 2 \\
$84-88$ & 1 \\
$79-83$ & 13 \\
$74-78$ & 13 \\
$\mathrm{~N}$ & 30 \\
\hline
\end{tabular}

Berdasarkan Tabel 6 tersebut dapat diketahui bahwa hasil postes kelompok eksperimen 1 yang memperoleh skor 94-98 sebanyak 1, yang memperoleh skor 89-93 sebanyak 2, yang memperoleh skor 84-88 sebanyak 1, yang memperoleh skor 79-83 sebanyak 13, dan yang memperoleh skor 74-78 sebanyak 13. Dari tabel di atas diketahui bahwa yang memperoleh frekuensi terbanyak terdapat pada interval 74-78 dan interval 79-83 yang masing-masing berjumlah 13 peserta didik.

Kelas Kontrol

Tabel 7. Distribusi Frekuensi Postes Kelas Kontrol

\begin{tabular}{c|c}
\hline Interval & Frekuensi \\
\hline $67-70$ & 2 \\
$63-66$ & 7 \\
$59-62$ & 12 \\
$55-58$ & 7 \\
$51-54$ & 1 \\
$47-50$ & 1 \\
$\mathrm{~N}$ & 30 \\
\hline
\end{tabular}

Berdasarkan Tabel 7 tersebut dapat diketahui bahwa hasil postes kelompok kontrol yang memperoleh skor 67-70 sebanyak 2, yang memperoleh skor 63-66 sebanyak 7 , yang memperoleh skor 59-62 sebanyak 12 , 
yang memperoleh skor 55-58 sebanyak 7, yang memperoleh skor 51-54 sebanyak 1, dan yang memperoleh skor 47-50 sebanyak 1. Dari tabel di atas diketahui bahwa yang memperoleh frekuensi terbanyak terdapat pada interval 59-62 yang berjumlah 12 peserta didik.

\section{Pengujian Hipotesis}

Apabila pengujian asumsi normalitas sebaran dan homogenitas varian telah terpenuhi, persyaratan parametrik uji hipotesis menggunakan Anava dan dilanjutkan uji Scheffe. Uji perbedaan nilai kemampuan menulis deskripsi baik kelas eksperimen maupun kontrol menggunakan uji Anava satu jalur. Selanjutnya, untuk menguji keefektifan ketiga model pembelajaran menulis deskripsi tersebut menggunakan uji Scheffe. Hipotesis yang diuji adalah sebagai berikut. Pertama, Ada perbedaan yang signifikan antara model kooperatif tipe concept sentence, model kooperatif tipe think-pair-share, dan model tradisional dalam pembelajaran menulis deskripsi peserta didik kelas VII SMP Negeri di Kabupaten Sleman. Kedua, ada keefektifan model kooperatif tipe concept sentence, model kooperatif tipe think-pair-share (TPS), dan model tradisional yang signifikan dalam pembelajaran menulis deskripsi peserta didik kelas VII SMP Negeri di Kabupaten Sleman.

\section{Uji Hipotesis Pertama}

Pada pengujian hipotesis pertama menggunakan Anava satu jalur dengan SPSS versi 17 yang disajikan pada Tabel 8 sebagai berikut.

Tabel 8 Ringkasan Uji Anava Postes

\begin{tabular}{lccccc}
\hline & $\begin{array}{c}\text { Sum of } \\
\text { Squares }\end{array}$ & df & $\begin{array}{c}\text { Mean } \\
\text { Square }\end{array}$ & F & Sig. \\
\hline $\begin{array}{l}\text { Between } \\
\text { Groups }\end{array}$ & 7080,067 & 2 & 3540,033 & 140,578 &, 000 \\
$\begin{array}{l}\text { Within } \\
\text { Groups }\end{array}$ & 2190,833 & 87 & 25,182 & & \\
\hline \multicolumn{1}{c}{ Total } & 9270,900 & 89 & & & \\
\hline
\end{tabular}

Berdasarkan hasil uji Anava tersebut, diperoleh nilai $F$ sebesar 140,578 dan signifikansi $(p)<0,05$. Jadi, dapat disimpulkan bahwa terdapat perbedaan yang signifikan antara model kooperatif tipe concept sentence, model koope- ratif tipe think-pair-share, dan model tradisional dalam pembelajaran menulis deskripsi peserta didik kelas VII SMP Negeri di Kabupaten Sleman.

\section{Uji Hipotesis Kedua}

Pada pengujian hipotesis kedua menggunakan Uji Scheffe dengan SPSS versi 17 yang disajikan pada Tabel 9 sebagai berikut.

Tabel 9 Ringkasan Hasil Uji Scheffe

\begin{tabular}{llrl}
\hline \multirow{2}{*}{ (I) Model } & (J) Model & $\begin{array}{c}\text { Mean } \\
\text { Difference } \\
(\mathrm{I}-\mathrm{J})\end{array}$ & Sig. \\
\hline \multirow{2}{*}{ Eksperimen1 } & Eksperimen2 & $-3,633^{*}$ &, 023 \\
& Kontrol & $16,733^{*}$ &, 000 \\
\multirow{2}{*}{ Eksperimen2 } & Eksperimen1 & $3,633^{*}$ &, 023 \\
& Kontrol & $20,367^{*}$ &, 000 \\
\multirow{2}{*}{ Kontrol } & Eksperimen1 & $-16,733^{*}$ &, 000 \\
& Eksperimen2 & $-20,367^{*}$ &, 000 \\
\hline
\end{tabular}

Berdasarkan tabel ringkasan hasil uji Scheffe pada Tabel 9, dirumuskan sebagai berikut. Hasil perhitungan dengan uji Scheffe diketahui antara penggunaan model kooperatif tipe concept sentence dan tipe think-pair-share dalam pembelajaran menulis deskripsi peserta didik kelas VII SMP N di Kabupaten Sleman, diperoleh probabilitas sebesar 0,023 lebih kecil dari taraf signifikansi yang ditetapkan, yaitu 0,05 (5\%) maka Ho ditolak dan Ha diterima. Kesimpulan pengujian hipotesis tersebut adalah terdapat keefektifan antara model tersebut dan nilai mean difference sebesar 3,633 yang artinya penggunaan model kooperatif tipe think-pairshare lebih efektif dibandingkan model kooperatif tipe concept sentence dalam pembelajaran menulis deskripsi peserta didik kelas VII SMP $\mathrm{N}$ di Kabupaten Sleman.

Hasil perhitungan dengan uji Scheffe tentang keefektifan antara penggunaan model kooperatif tipe concept sentence dan model tradisional dalam pembelajaran menulis deksripsi peserta didik kelas VII SMP N di Kabupaten Sleman diperoleh probabilitas (p) sebesar 0,000 yang lebih kecil dari taraf signifikansi yang ditetapkan, yaitu $0,05(5 \%)$ maka terdapat perbedaan keefektifan, artinya kesimpulan dari pengujian ini adalah terdapat perbedaan keefektifan antara penggunaan model koope- 
ratif tipe concept sentence dan model tradisional dalam pembelajaran menulis deksripsi peserta didik kelas VII SMP N di Kabupaten Sleman. Selanjutnya, nilai mean difference sebesar 16,733 yang artinya model kooperatif tipe concept sentence lebih efektif dibandingkan model tradisional.

Secara keseluruhan hasil perhitungan dengan uji Scheffe tentang keefektifan antara penggunaan model kooperatif tipe think-pairshare dan model tradisional dalam pembelajaran menulis dekripsi peserta didik kelas VII SMP $\mathrm{N}$ di Kabupaten Sleman diperoleh probabilitas (p) sebesar 0,000 lebih kecil dari taraf signifikansi yang ditetapkan, yaitu 0,05 (5\%). Dapat disimpulkan terdapat perbedaan yang signifikan antara model kooperatif tipe think-pair-share dan model tradisional dalam pembelajaran menulis deksripsi peserta didik kelas VII SMP $\mathrm{N}$ di Kabupaten Sleman, sedangkan nilai mean difference antara kedua model pembelajaran tersebut sebesar 20,367 sehingga dapat disimpulkan bahwa model pembelajaran kooperatif tipe think-pair-share lebih efektif dibandingkan model tradisional. Jadi, secara keseluruhan hasil yang diperoleh melalui uji Scheffe adalah penggunaan model kooperatif tipe think-pair-share dalam pembelajaran menulis deksripsi peserta didik kelas VII SMP N di Kabupaten Sleman merupakan model pembelajaran yang paling efektif, kemudian urutan selanjutnya adalah model kooperatif tipe concept sentence, dan urutan yang terakhir adalah model tradisional.

\section{Pembahasan}

Pada bagian ini dikemukakan pembahasan terhadap hasil-hasil penelitian yang meliputi (1) ada perbedaan yang signifikan antara model kooperatif tipe concept sentence, model kooperatif tipe think-pair-share, dan model tradisional dalam pembelajaran menulis deskripsi peserta didik kelas VII SMP Negeri di Kabupaten Sleman dan (2) ada keefektifan model kooperatif tipe concept sentence, model kooperatif tipe think-pair-share (TPS), dan model tradisional dalam pembelajaran menulis deskripsi peserta didik kelas VII SMP Negeri di Kabupaten Sleman.

Ada Perbedaan yang Signifikan Antara Model Kooperatif Tipe Concept Sentence,
Model Kooperatif Tipe Think-Pair-Share, dan Model Tradisional dalam Pembelajaran Menulis Deskripsi Peserta Didik Kelas VII SMP Negeri di Kabupaten Sleman

Secara keseluruhan dari perhitungan Anava tentang penerapan model pembelajaran kooperatif antara model kooperatif tipe concept sentence, model kooperatif think-pair-share, dan model tradisional dalam pembelajaran menulis deskripsi peserta didik kelas VII SMP N di Kabupaten Sleman menghasilkan signifikansi (p) < dari taraf signifikansi yang ditentukan, yaitu $0,05(p=0,000<0,05)$. Kesimpulannya adalah terdapat perbedaan antara penerapan model kooperatif tipe concept sentence, thinkpair-share, dan tradisional dalam pembelajaran menulis deskripsi peserta didik kelas VII SMP $\mathrm{N}$ di Kabupaten Sleman.

Ada Keefektifan Model Kooperatif Tipe Concept Sentence, Model Kooperatif Tipe Think-Pair-Share (TPS), dan Model Tradisional dalam Pembelajaran Menulis Deskripsi Peserta Didik Kelas VII SMP Negeri di Kabupaten Sleman

Berdasarkan hasil uji Scheffe tentang keefektifan antara penerapan model kooperatif tipe concept sentence dan think-pair-share diperoleh signifikansi (p) sebesar 0,023 < dari taraf signifikansi 0,05. Hasil uji Scheffe tentang keefektifan antara penerapan model kooperatif tipe concept sentence dan model tradisional diperoleh signifikansi $(\mathrm{p})<$ dari taraf signifikansi 0,05, sedangkan hasil uji Scheffe tentang keefektifan antara penerapan model kooperatif tipe think-pair-share dan model tradisional diperoleh signifikansi (p) dan tradisional diperoleh signifikansi (p) < dari taraf signifikansi 0,05. Jadi, dapat disimpulkan bahwa model kooperatif tipe think-pair-share paling efektif daripada model kooperatif tipe concept sentence dan tradisional dalam pembelajaran menulis deskripsi peserta didik kelas VII SMP N di Kabupaten Sleman. Adapun urutan model pembelajaran kooperatif yang paling efektif dalam pembelajaran menulis deskripsi peserta didik kelas VII SMP N di Kabupaten Sleman adalah (a) model pembelajaran kooperatif tipe think-pair-share, (b) model kooperatif tipe concept sentence, dan model tradisional. 


\section{SIMPULAN}

Berdasarkan analisis data dan pembahasan, penelitian ini dapat disimpulkan sebagai berikut. Pertama, ada perbedaan yang signifikan antara model kooperatif tipe concept sentence, model kooperatif tipe think-pair-share, dan model tradisional dalam pembelajaran menulis deskripsi peserta didik kelas VII SMP Negeri di Kabupaten Sleman dengan nilai $F$ sebesar 140,578 dan signifikansi $(p)<0,05$. Kedua, model kooperatif tipe think-pair-share paling efektif dibandingkan model kooperatif tipe concept sentence dan model tradisional dalam pembelajaran menulis deskripsi peserta didik kelas VII SMP Negeri di Kabupaten Sleman dengan nilai signifikansi $(\mathrm{p})<$ dari taraf signifikansi yang telah ditetapkan, yaitu $0,05(5 \%)$. Jadi, urutan model pembelajaran yang paling efektif adalah model kooperatif tipe think-pairshare, model kooperatif tipe think-pair-share, dan model tradisional.

\section{DAFTAR PUSTAKA}

Arends, R.L. 2008. Learning to each. ( $7^{\text {th }}$ ed). (Terjemahan Helmi Prajitno Soetjipto., \& Sri Mulyantini Soetjipto). New York: McGraw Hill Companies. (Buku asli diterbitkan tahun 2007).

Brown, H.D. 2003. Language assesment principles and classroom practices. New York: Longman.

Campbell, D.T. \& Stanley, J.C. 1972. Experimental and quasi experimental designs for research. Chicago: Rand Menally \& Company.

Keraf, G. 1981. Eksposisi dan deskripsi. Jakarta: Nusa Indah.

Huda, Miftahul. 2014. Model-model pengajaran dan pembelajaran. Yogyakarta: Pustaka Pelajar. 